\title{
The Influence of the International Covenant on Civil and Political Rights on the Death Penalty Legislation in China
}

\author{
Sixue Xiao \\ School of Arts and Law \\ Wuhan University of Technology \\ Wuhan, China
}

\begin{abstract}
The International Covenant on Civil and Political Rights provides international guidelines that strictly limit the application of the death penalty and ultimately abolish the death penalty. Generally speaking, China's death penalty legislation is basically consistent with the provisions of the Covenant, but there are still gaps with it in some specific provisions. In order to better link with the Covenant, the crimes and targets applicable to the death penalty should be reduced, and the system of death penalty with reprieve should be improved, so that the death penalty legislation of our country can be coordinated with international human rights standards.
\end{abstract}

\section{Keywords—death penalty; Covenant; criminal law}

\section{INTRODUCTION}

The International Covenant on Civil and Political Rights (hereinafter referred to as the Covenant), as one of the world's charters of human rights, specifically stipulates the individual rights and fundamental freedoms such as civil and political rights by legal means, and lays a legal foundation for human rights protection in the world. The Government of China signed this Covenant on October 5, 1998. Later, in the constitutional amendment adopted on March 14, 2004, a paragraph was added to Article 33 of the Constitution as the Third Paragraph: "The State respects and protects human rights", raising the protection of human rights to a constitutional principle. The Covenant specifically stipulates the problem of the death penalty in six paragraphs Article 6 . Generally speaking, our country's death penalty legislation is basically consistent with the provisions of the Covenant, but there are still gaps in some specific provisions. In order to better link with the Covenant and coordinate the development of China's death penalty legislation with the international human rights standards, it is necessary to revise and improve some of the shortcomings in China's death penalty legislation.

\section{CRIMES APPLICABLE TO THE DEATH PENALTY}

"Every human being has the inherent right to life. This right should be protected by law. No one shall be arbitrarily deprived of his life." "In countries which have not abolished the death penalty, sentence of death may be imposed only for the most serious crimes." "Nothing in this article shall be invoked to delay or prevent the abolition of capital punishment by any State Party to the present Covenant." These are the contents of the Paragraph 1, 2, 6 of Articles 6 in the Covenant. It can be seen from these provisions: Firstly, the abolition of the death penalty is the ultimate goal. "A punishment, to be just, should have only that degree of severity which is sufficient to deter others. Now there is no man whop upon the least reflection, would put in competition the total perpetual loss of his liberty, with the greatest advantages he could possibly obtain in consequence of a crime. Perpetual slavery, then, has in it all that is necessary to deter the most hardened and determined, as much as the punishment of death." "With the trend of history, it can be predicted that the death penalty will be abolished in countries around the world the future the future." Secondly, in countries that have not abolished the death penalty, the application of the death penalty is strictly limited. The death penalty cannot be applied to just "severe" crimes, but only to the "severest" crimes.

China's Criminal Law of 1997 stipulated ten types of crimes in specific provisions. Apart from to the crime of malfeasance, the remaining nine crimes all have provisions for the death penalty. Among them: there are 7 death penalty charges in the crime against national security, 14 death penalty charges in the crime against public security, 16 death penalty charges in the crime against the socialist market economic order, 5 death penalty charges in the crime against citizens' personal rights and democratic rights, 8 death penalty charges in the crime against social management order, 14 death penalty charges in the crime against national military interests and national defense interests, and 2 death penalty charges in the crime of corruption, bribery and property infringement. In Japan, only a dozen crimes, such as crimes of civil strife, treason and assisting treason, have provisions of death penalty, and they are more and more cautious in the application of the death penalty. In the United States, the states that reserve the death penalty believe that the death penalty only applies to the first-degree murder as the severest crime. It can be seen that China's Criminal Law of 1997 had quite a few provisions on death penalty charges from the perspectives of the type of charges, the number of charges, the absolute numbers or the relative numbers. 
Article 48 of the Criminal Law of 1997 stipulates: "The death penalty applies only to criminals with extremely severe crimes." This is consistent with the provisions of Paragraph 2, Article 6 of the Covenant. However, do all of the charges applicable to the death penalty stipulated in the current Criminal Law of our country have the characteristics of "extremely severe crimes" or "severest crimes"? I believe this is not the case. It is generally believed that crimes against national security, public safety and citizens' personal rights are the severest. There are provisions of death penalty for these types of crimes, which have certain rationality under the current circumstances. However, it is unreasonable to stipulate the death penalty for crimes against social management order and non-violent economic crimes and property crimes, because these crimes have not reached the degree of severity stipulated in Article 48 of the Criminal Law and Paragraph 2, Article 6 of the Covenant. If the death penalty is also provided for these crimes, it will inevitably violate the Covenant's spirit of strictly restricting the application of the death penalty. For example, Article 295 of the Criminal Law of 1997 stipulates that the death penalty can be imposed on the crime of imparting criminal methods if the circumstances are particularly severe. However, as far as the crime of imparting crime methods is concerned, no matter how severe the circumstances is, it is hard to imagine that such crimes will have social harm equivalent to crimes against national security, public security and citizens' personal rights. It is too heavy to stipulate the death penalty for it, which is not in line with the trend of lightening the penalty in the world today. For another example, Article 328 of the Criminal Law of 1997 stipulates the crime of excavating and robbing ancient cultural sites, ancient tombs, ancient human fossils and ancient vertebrate fossils, and that the death penalty can also be imposed in some cases. In fact, this is not in line with the psychology of ordinary people or the concept of law. For another example, Article 264 of the Criminal Law of 1997 stipulates the crime of theft, and that the death penalty can be imposed in one of two situations: "theft of financial institutions with a particularly large amount" and "theft of precious cultural relics with severe circumstances". Before the Criminal Law of 1997, cases of imposing death sentence on theft were not rare. However, the current Criminal Law only considers that theft may be sentenced to death only in one of the two serious situations mentioned above, and in other cases, no matter how large the amount of theft, how severe the circumstance is, the death penalty will not be imposed. Undoubtedly, the Criminal Law of 1997 greatly reduces the scope of the death penalty for theft, which is commendable, but it still has not completely eliminated the possibility of being sentenced to death for theft. Therefore, people still feel that non-violent property crimes such as theft will be sentenced to death in some cases because the value of property is comparable to the value of human life in some cases, otherwise, why is a violent property crime sentenced to death?

Through the above analysis, the author suggests to abolish the application of the death penalty to the crimes against social management order and non-violent economic crimes and property crimes, and limit the application of the death penalty to the crimes against national security, public security and citizens' personal rights. This is in line with the trend of penal development in the world today, and it can be well linked with the Covenant.

\section{RESTRICTIONS ON THE APPLICABLE TARGETS OF THE DEATH PENALTY}

Article 49 of the Criminal Law of 1997 stipulates that "the death penalty shall not apply to people who are under the age of 18 at the time of the crime and women who are pregnant at the time of the trial." Paragraph 5, Article 6 of the Covenant provides: "criminals who are under the age of 18 shall not be sentenced to death; the death penalty shall not be imposed on pregnant women." By comparison, it is found that the provisions of Article 49 of the Criminal Law of China are spiritually basically consistent with those of Article 6 of the Covenant. The difference is that China's Criminal Law only limits to the women who are pregnant at the time of the trial when stipulating that "the death penalty shall not apply to pregnant women", while the Covenant obviously means that the death penalty shall not apply to women who are pregnant at any stage from the filing of the case to the execution of punishment when stipulating that "the death penalty may not be imposed on pregnant women". Such regulation is much broader than the provisions of our Criminal Law. I believe that such provisions of China's Criminal Law may at least lead to the following problems:

\section{A. There Are Differences in Defining the "Time of Trial"}

What is the "time of trial"? When does the period of "trial time" start and when does it end? Different methods of definition may result in different penalties for the same pregnant woman. On August 4, 1998, the judicial interpretation of the Supreme People's Court clearly stated that pregnant women who are indicted for the same fact and brought to trial after spontaneous abortion during pretrial detention for being suspected of crime shall be deemed to be "pregnant women at the time of trial", to whom the death penalty is not applicable according to law. It is undeniable that the judicial interpretation of the Supreme People's Court helps to limit the application of the death penalty. However, this judicial interpretation only considers that the death penalty does not apply to pregnant women who are spontaneously aborted during pretrial detention for being suspected of crime... according to law. Then, can the death penalty be applied to pregnant women who have childbirth or induced abortion during pretrial detention for being suspected of crime? According to the judicial interpretation, obviously the death penalty can be applied. The question is, why is the death penalty not applied after spontaneous abortion but it can be applied after childbirth or induced abortion? This is logically unreasonable. In addition, if can the death penalty be applied to pregnant women who are spontaneously aborted during guaranteed pending trial or residential surveillance for being suspected of crime? According to the judicial interpretation, obviously the death penalty can also be applied. Why is the death penalty not applied to the spontaneous abortion during pretrial detention, while it is applied to the spontaneous abortion during guaranteed pending trial or residential surveillance? This is also unreasonable logically. 


\section{B. Women Who Are Pregnant Before the Execution of the Death Penalty After the Trial Are Not Given the Protection They Deserve}

China's Criminal Law stipulates that "the death penalty is not applied to women who are pregnant at the time of trial." Then, if women are pregnant for various reasons before the execution of the death penalty after the trial, according to the provisions of our Criminal Law, since the women are not pregnant at the time of trial, and therefore it does not belong to the situation where the death penalty is not applicable. In other words, the death penalty can be applied to such situation based on the provisions of our Criminal Law. The Covenant stipulates that "the death penalty shall not be imposed on pregnant women." According to the Covenant, it is obvious that the death penalty is not applied to women who are pregnant before the execution of the death penalty after the trial. If the death penalty is not applied to the situation where the criminal women are pregnant before the execution of the death penalty after the trial, it complies with the provisions of the Covenant, but it does not comply with the relevant provisions of China's Criminal Law; if the death penalty is applied to such situation, it complies with provisions of China's Criminal Law, but it does not comply with people's legal feelings, or the provisions of the Covenant.

\section{It Is Easy to Cause People to Evade the Law}

Since the Criminal Law of our country stipulates that "the death penalty is not applied to women who are pregnant at the time of trial", it makes it possible for some people to exploit loopholes of laws in some cases. For example, some judicial personnel may wish to apply the death penalty to pregnant women for various reasons. Since they well know that the death penalty is not applied to women who are pregnant at the time of trial, they do not try pregnant women intentionally, and try them after they have spontaneous abortion, induced abortion or childbirth, so as to evade the provision that "the death penalty is not applied to women who are pregnant at the time of trial".

Through the above analysis, I suggest that China's Criminal Law directly adopt the provision that "the death penalty is not applicable to pregnant women", so that the death penalty is not applied to woman who are pregnant at any stage from filing of the case to the execution of the penalty. Such a provision is both in line with the humanitarian spirit and can be well linked to the Covenant, and it can also solve the above problems.

\section{ON THE IMPROVEMENT OF THE SYSTEM OF DEATH PENALTY WITH REPRIEVE}

"The system of death penalty with reprieve is an originality of China's criminal legislation. The establishment of this system is of great significance for the implementation of the policy of killing fewer people, reducing the applicable scope of the death penalty, and promoting criminals repent and start anew." Internationally, China's original system of death penalty with reprieve has been widely praised. During the review of Japan's draft criminal law, it also specifically proposed to adopt China's system of death penalty with reprieve. The second half of the first paragraph of Article 48 of
China's Criminal Law of 1997 stipulates: "For criminals who should be sentenced to death, if they are not required to be executed immediately, they may be sentenced to death with a reprieve for two years." Article 50 of the Criminal Law of 1997 stipulates: "If the people who have been sentenced to the death with reprieve do not commit intentional crime during the reprieve, after the expiration of the two-year period, the penalty may be reduced to life imprisonment; if they have significant meritorious services, after the expiration of the twoyear period, the penalty may be reduced to fixed-term imprisonment of not less than fifteen years and not more than twenty years; if intentional crime is committed and is verified, the death penalty is executed with the Supreme People's Court approval." The system of death penalty with reprieve helps to strictly limit the death penalty, which is consistent with the Covenant's spirit to strictly restrict the death penalty. At the same time, I believe that China's current system of death penalty with reprieve should be improved from the following aspects to be better linked to the Covenant.

\section{A. For Criminals Who Should Be Sentenced to Death, It Should Not Distinguish Whether They Must Be Executed Immediately, and the Death Penalty Should Be Uniformly Imposed with a Reprieve of Two Years}

According to the provisions of Article 48 of the Criminal Law of 1997, criminals who should be sentenced to death can be executed immediately, or they can be sentenced to death with a reprieve of two years, and the boundary line is whether they must be executed immediately. I believe that such a provision is not reasonable. First of all, the standard of "whether it must be executed immediately" is difficult to grasp objectively and fairly. In the same case, different people may come to different conclusions when judging "whether they must be executed immediately". Even the same person may have different feelings about "whether they must be executed immediately" in the same case at different time. It stands to reason that those who judge "whether they must be executed immediately" should not have their own emotions and positions, but should always remain objective and neutral. However, this is only a state of what it ought to be, not a state of reality. In fact, it is difficult for people who judge "whether they must be executed immediately" to completely get rid of their emotions and positions and achieve complete objectivity and neutrality. In the face of the sacred right to life, it is unacceptable if the immediate execution of the death penalty is determined with more or less of one's own emotions and positions. Secondly, after the immediate execution of death penalty, if it is found to be a false judgment, it is likely that the death penalty has been actually executed and it is impossible to redeem valuable life. In judicial practice, cases of misjudgment have occurred from time to time for various reasons. Although the judicial workers have made unremitting endeavor and achieved great progress in reducing misjudgment, due to the influence of various factors, cases of misjudgment cannot be absolutely avoided. If a misjudgment can be corrected after the sentence of death penalty with reprieve, life imprisonment and fixed-term imprisonment, a valuable life cannot be redeemed if a misjudgment is found after the immediate execution of the death penalty since the death penalty has been actually executed. Through the above analysis, I believe that criminals 
who should be sentenced to death uniformly with a reprieve of two years.

\section{B. Further Improving the Provisions for the Reduction of Punishment for Rendering Meritorious Service During the Execution of the Death Penalty with Reprieve}

According to the provisions of Article 50 of the Criminal Law of 1997, if the perpetrators who have been sentenced to the death with reprieve do not commit intentional crime during the reprieve, after the expiration of the two-year period, the penalty may be reduced to life imprisonment; if they have significant meritorious services, after the expiration of the twoyear period, the penalty may be reduced to fixed-term imprisonment of not less than fifteen years and not more than twenty year. What if the perpetrators have neither intentional crime nor significant meritorious service, but have common meritorious service? Strictly according to Article 50 of the Criminal Law of 1997, perpetrators who do not commit intentional crime and have common meritorious service should be treated the same as those who commit no intentional crime and have no meritorious service, and the penalty is reduced to life imprisonment after the expiration of the two-year period. However, it is obviously unfair to reduce the death penalty of perpetrators in two different situations to life imprisonment without distinction. It not only ignores the difference in the degree of reform and education between the two and weakens the enthusiasm of the criminals sentenced to death penalty with reprieve to render meritorious service for the reduction of punishment, but is not conducive to the further reform of the criminals sentenced to death penalty. I suggest reducing the penalty of perpetrators who do not commit intentional crime and have common meritorious service to fixed-term imprisonment of not less than fifteen years and not more than twenty years after the expiration of the two-year period. Some people may ask: Will it be unfair for to reduce the penalty of perpetrators with common meritorious services and significant meritorious services both to fixed-term imprisonment of not less than fifteen years and not more than twenty years after the expiration of the two-year period? I believe that this concern is not necessary. The fixed-term imprisonment of not less than fifteen years and not more than twenty years is a magnitude penalty. For those who have common meritorious services and those who have significant meritorious services, the number of years of fixed-term imprisonment after the expiration of the two-year period shall be determined based on the meritorious service and other circumstances, and the number of years of fixed-term imprisonment for the two is not necessarily the same, which will not lead to injustice, and can also encourage the perpetrators to make further contributions and even make great contributions.

\section{Those Who Commit Intentional Crimes During the Execution of Death Penalty with Reprieve Should Be Treated Differently, and the Death Penalty Should Not Be Executed Uniformly}

According to the provisions of Article 50 of the Criminal Law of 97, if perpetrators who have been sentenced to death penalty with reprieve commit intentional crime during the execution, which is verified, the death penalty shall be executed with the approval of the Supreme People's Court. The scope of intentional crimes is broad, including minor intentional crimes, heavy intentional crimes and serious intentional crimes. Strictly according to the provisions of Article 50 of the Criminal Law of 1997, as long as the prisoners sentenced to death with reprieve intentionally commit crimes during the execution of the death penalty with reprieve, even if it is a minor intentional crime, even if a minor intentional crime caused by the victim's fault or even serious fault, the death penalty should be executed. Such indiscriminate provisions are obviously too absolute and mechanical. It is unfair because the personal danger and degree of reform and education of different prisoners sentenced to death with reprieve are not fully considered. Such general provisions are not conducive to giving play to the system of death penalty with reprieve in strictly limiting the application of the death penalty, and runs counter to the original purpose of establishing the system of death penalty with reprieve. Imagine a prisoner sentenced to death with reprieve who is eager to reduce his/her penalty from the bottom of his/her heart has already recognized his/her own mistakes and has already expressed repentance, if he/she is sentenced to death due to just a minor intentional crime due to momentary impulse caused by the victim's serious fault, it will not only lead to distrust of the law, but also triggers the sympathy of the public. Under such circumstances, it is easier for prisoners sentenced to death with reprieve to go astray, who may even commits more serious intentional crimes with a "psychology of throwing the handle after the blade". This obviously affects the positive role of the system of death penalty with reprieve. Through analysis, I believe that during the execution of the death penalty with reprieve, the death penalty can only be executed if the prisoners commit serious intentional crimes. This complies with the spirit of humanitarianism and can be well linked with the provisions of the Covenant that strictly limit the application of the death penalty, and can also give full play to the positive role of the system of death penalty with reprieve.

\section{CONCLUSION}

In summary, I propose the following suggestions for China's current system of death penalty with reprieve: 1 . Criminals who should be sentenced to death should not be distinguished whether they must be executed immediately, but should be sentenced to death with a reprieve with two years. 2 Further improve the provisions for the reduction of penalty during the execution of the death penalty with reprieve. 3. Prisoners committing intentional crimes during the execution of the death penalty with reprieve should be treated differently, and the death penalty should not be executed to all of them.

\section{REFERENCES}

[1] [Italy] Beccaria: On Crime and Punishment, translated by Huang Fengyi, China Legal Publishing House, 2005 edition, p. 59.

[2] [Japan] Kawabata: The General Theory of Criminal Law, Cheng Wentang, 1997 edition, p. 652.

[3] [Japan] Otani: The General Theory of Criminal Law, translated by Li Hong, China Renmin University Press, 2008 edition, p. 459. 
[4] [Japan] Otsuka: Introduction to the Criminal Law (General), Yuhikaku Publishing, 1987 edition, p. 458.

[5] Jia Yu: Rational Thinking and Realistic Choice of Death Penalty, in Chinese Journal of Law, No. 2, 1997.

[6] Chief editor Mark Chang: Criminal Law, Higher Education Press, 2017 edition, p. 242.

[7] Chief editor Mark Chang: General Theory of Penalty, Wuhan University Press, 1999 edition, p. 117. 